\title{
E1 Resguardo de la Aduana durante el proceso revolucionario en Salta (1810-1817)*
}

\author{
Bárbara Marisa Aramendi**
}

Recibido el 4 de junio de 2019; aceptado el 27 de noviembre de 2019

\section{RESUMEN}

El presente trabajo estudia los mecanismos de control y recaudación de la Hacienda descendiendo a la cotidianeidad administrativa y política mediante el análisis de los guardas de Salta y Jujuy. Nos preguntamos quiénes ocuparon esos cargos, cuáles fueron sus funciones, cómo y dónde las ejercieron en un contexto donde el orden político empezaba a percibirse como parte de una monarquía en crisis. El interés por esta problemática se centra en el convencimiento de que la organización y funcionamiento del Resguardo y guardas de la Hacienda durante el proceso revolucionario revistieron una dinámica propia que merece un estudio específico. Para llevar a cabo el presente trabajo se consultaron los Fondos de Gobierno del Archivo y Biblioteca Históricos de Salta.

Palabras clave: Guardas, Hacienda, proceso revolucionario.

* Este trabajo forma parte de los proyectos CIUNSa 2476: "Configuraciones sociales, culturales y del poder entre colonia y siglo XIX. Salta y Jujuy en el espacio sur andino, 19601852”, dirección y codirección doctoras Telma Chaile y Bárbara Aramendi; IDEA: “Territorialidad y poder. Conflictos, exclusión y resistencias en la construcción de la sociedad en Salta”, bajo la dirección de la doctora Sara Mata.

** Consejo Nacional de Investigaciones Científicas y Técnicas, Universidad Nacional de Salta, Salta, Argentina. Correo electrónico: barbara_aramendi@yahoo.com.ar.

ORCID: https://orcid.org/0000-0001-8372-9240 


\title{
Custom house guards during the revolutionary process in Salta (1810-1817)
}

\begin{abstract}
The present article studies the control and collection mechanisms of Treasury deepening to the administrative and political daily life through the analysis of the guards of Salta and Jujuy. We ask who occupied those positions, what were their functions, how and where they were exercised in a context where the political order began to be perceived as part of a monarchy in crisis. Our interest in this problem is centered on the conviction that the organization and operation of the Resguardo and guards during the revolutionary process had a specific dynamic that deserves a specific study. The sources used for this approach consist of the Fondos de Gobierno del Archivo y Biblioteca Históricos de Salta.
\end{abstract}

Key words: Guards, Treasury, revolutionary process.

$\mathrm{E}_{\mathrm{sec}}^{1}$ l estudio de la Hacienda del siglo XIX, concebida como un espacio sociopolítico, se constituye como uno de los campos que mejor se presta para el análisis de las rupturas propiciadas por movimientos revolucionarios que insertan sus raíces en las últimas décadas del XVIII. Los trabajos dedicados a la negociación fiscal, a la nueva organización de la administración de Hacienda, a sus programas, al fraude o al control financiero surgido en esos años, subrayan la pervivencia de concepciones antiguas. ${ }^{1}$

La Real Hacienda en la colonia constituía un sector administrativo estratégico, en particular a través de su función de recaudación, por medio de su engranaje aseguraba el tránsito de las riquezas americanas destinadas a la metrópoli o al funcionamiento local del aparato del Estado colonial. ${ }^{2}$ La importancia recaudatoria inherente a esta institución perdura lógicamente durante el proceso revolucionario, es en ese contexto que elegimos analizar la administración de la Real Hacienda enfocándonos en el grupo de oficiales encargado de celar los puestos del camino entre Salta y el Alto Perú. Nos centramos específicamente en el estudio de los miembros del Resguardo de

Dubet y Solbes Ferri, “Introducción”.

Bertrand, Grandeza y miseria del oficio. Los oficiales de la Real Hacienda de la Nueva España, siglos XVII у XVIII, p. 19. 
la Aduana y en el de los guardas que actuaron en Jujuy en complementariedad con aquéllos.

Los estudios sobre la administración son abundantes en la historiografía, desde fines de los sesenta algunos planteos fundantes analizaron a la monarquía hispánica confrontándola con los tipos de dominación propuestos por Max Weber. John Leddy Phelan trabajó sobre la capacidad de negociación y autonomía de los agentes representantes de la Corona definiendo la burocracia española en la época de los Habsburgos como una burocracia a medio camino entre una administración patrimonial y una moderna. ${ }^{3}$ Por su parte, Horst Pietschmann dedicó sus estudios al análisis del proceso de formación del orden estatal colonial desarrollando el tema de la administración en el virreinato de Nueva España y la implantación allí del Sistema de Intendencias. $^{4}$

Abocado al estudio de las reformas borbónicas John Lynch brindó una visión del funcionamiento del virreinato del Río de la Plata a partir de la implantación del Sistema de Intendencias. Para ello llevó a cabo un análisis de la situación particular de la región, su evolución dentro del sistema de gobierno español y la manera en que los intendentes actuaron en relación a otras instituciones y oficiales de la corona. ${ }^{5}$ Siguiendo los lineamientos trazados por Lynch, John Fisher, en su trabajo sobre la administración provincial bajo el régimen de las intendencias en Perú, exploró los antecedentes y efectos de la reforma administrativa durante el último período colonial y examinó los logros de los intendentes en relación a lo previsto por la Ordenanza. ${ }^{6}$

Desde fines de los setenta y en las décadas subsiguientes, distintas obras abordaron el estudio de miembros de la administración a partir de criterios socioprofesionales. Destacamos la clásica obra de Mark Burkholder y Dewitt Chandler ${ }^{7}$ sobre los oidores de las Audiencias y el pretendido enfrentamiento entre criollos y peninsulares, el trabajo de Linda Arnold ${ }^{8}$ para México donde analiza a la burocracia y a los burócratas en el período mo-

3 Phelan, El Reino de Quito en el siglo XVII. La política burocrática en el Imperio Español.

4 Pietschmann, Las reformas borbónicas y el sistema de intendencias en Nueva España. Un estudio político administrativo.

5 Lynch, Administración colonial española: el sistema de intendencias en el Virreinato del Río de la Plata.

6 Fisher, Gobierno y sociedad en el Perú colonial. El régimen de las Intendencias: 17841814.

7 Burkholder y Chandler, De la impotencia a la autoridad, la corona española y las audiencias en América, 1687-1808.

8 Arnold, Burocracia y burócratas en México, 1742-1835. 
nárquico y su tránsito a una república federal, y el de Susan Socolow ${ }^{9}$ sobre los burócratas de Buenos Aires a fines del período colonial.

A partir de la década de los noventa los trabajos de José María Imizcoz, Jean Pierre Dedieu y sus colaboradores analizaron la administración de la monarquía hispana con una renovada mirada historiográfica basados en el análisis microhistórico de las redes sociales para comprender la inserción de grupos familiares dentro del aparato institucional del Antiguo Régimen. Así, llevaron a cabo una amplia investigación relativa al estudio del sistema político y los vínculos entre los actores corporativos, magistrados e individuos proponiéndose superar los tradicionales acercamientos prosopográficos al cruzarlos con una historia institucional basada en procesos. ${ }^{10}$ Dentro de este paradigma Michel Bertrand estudia a los cuerpos de oficiales de la Real Hacienda de Nueva España en los siglos XVII y XVIII profundizando en el mundo personal, social y profesional de los implicados. ${ }^{11}$

Centrados en el estudio de la historia de las finanzas y también privilegiando la observación sobre los agentes que la constituyeron, en los últimos años una serie de trabajos se han preocupado por el análisis de la Real Hacienda de la monarquía, su significado y su existencia. Para ello consideraron este objeto de estudio en su calidad de espacio político, social y de negociación examinado los problemas fiscales en su interdependencia con transformaciones económicas, sociales y culturales. ${ }^{12}$

Dentro de este amplio abanico de producciones difícil de rastrear, sin embargo, son aquellas relativas a personajes actuantes en los espacios rasos de la administración, como los guardas, que constituían el grupo de los funcionarios menores tal como los denominara Mark Burkholder. ${ }^{13}$

9 Socolow, The Bureaucrats of Buenos Aires, 1769-1810: Amor al Real Servicio.

10 Citaremos sólo un par de obras de referencia, pues dichos grupos de investigación han publicado una cantidad considerable de artículos donde analizaron a la monarquía hispánica y su administración. Castellano, Dedieu, López Cordón (eds.), La pluma, la mitra y la espada. Estudios de Historia Institucional en la Edad Moderna. Imízcoz, Redes familiares y patronazgo. Aproximación al entramado social del País Vasco y Navarra en el Antiguo Régimen (siglos $X V$-XIX).

11 Bertrand, "De la familia a la red de sociabilidad”; Grandeza y miseria del oficio. "Los oficiales reales de Nueva España: una aproximación al estudio de un grupo de poder en la sociedad novohispana (siglos XVII-XVII)"; “Los oficiales de la Real Hacienda de la Nueva España, siglos XVII y XVIII”.

12 Bertrand y Moutoukias, Cambio institucional y fiscalidad; Dubet y Solbes Ferri, Monográfico "Actores políticos y actores privados en el gobierno de la Hacienda”; Dubet y Solbes Ferri, Dossier "La construcción de la hacienda hispánica en el largo siglo XVIII”. Sólo por mencionar trabajos colectivos recientes sobre la materia.

13 Burkholder distingue cuatro tipos de servidores del rey con el ánimo de diferenciar grupos dentro de un universo bastante amplio. Burkholder, "Burócratas”, p. 112. Horst Pietschmann hace lo propio, aunque organiza la división en tres grupos diferentes. Pietschmann, Las re- 
Para el caso de Salta, los abordajes específicos sobre la administración estuvieron vinculados casi exclusivamente a una tradicional historia de las instituciones que consideró que la existencia de una organización institucional estatal podía plantearse recién a partir de 1821, momento en que se sancionó el Reglamento de la provincia, se conformaron los tres poderes y se edificó un sistema fiscal y rentístico basado en medidas que fueron organizando las finanzas y la administración públicas. ${ }^{14}$ La problemática que aquí presentamos abarca un momento definido por esa historia como “caótico”, sin embargo, antes de 1821 nos encontramos, en el ámbito del control fiscal, con un cuerpo administrativo que funcionaba desde los primeros años del siglo XIX, pero con antecedentes seculares, con una historia, normativa y características propias. Partimos así, de la concepción de que las instituciones, lejos de ser producto de una fatalidad, son el resultado de una serie de decisiones; por lo tanto, su vitalidad, prospección y razón de ser está vinculada con la agencia de los sujetos que la componen y con las relaciones sociales en su conjunto. ${ }^{15}$ Pretendemos entonces comprender los mecanismos de control y recaudación de la Hacienda concebida como un espacio social y político, descendiendo a la cotidianeidad administrativa y política mediante el análisis de los guardas. Nos preguntamos quiénes ocuparon esos cargos, cuáles fueron sus funciones, cómo, dónde y por qué las ejercieron. Durante el período revolucionario el orden político empezaba a percibirse como parte de una monarquía en crisis al tiempo que no concretaba la condición de ser un órgano independiente para darse una organización constitucional moderna. ${ }^{16}$ Así, el interés por el estudio de los guardas y sus funciones cotidianas se centra en el convencimiento de que la organización y funcionamiento del Resguardo durante el proceso de independencia revistieron una dinámica propia que merece un estudio específico.

Pensar cómo se manejó ese sector de la Hacienda en tiempos de revolución en un territorio convertido en escenario de guerra y cuáles fueron los cambios y permanencias que se vislumbraron, posibilita acercarse a las prác-

formas borbónicas y el sistema de intendencias en Nueva España. Un estudio político administrativo.

14 El Reglamento constitucional de 1821 se sancionó luego del armisticio con el ejército realista del comandante Pedro Antonio de Olañeta, firmado a un mes de la muerte de Güemes. Según de la Cuesta fue redactado para que el futuro gobernador intendente tuviera reglas precisas para una recta administración de la provincia. de la Cuesta, Organización Institucional de Salta (1821-1855), pp. 8-10. Conti, "Reordenamiento de las rentas fiscales en la emergencia de los estados provinciales. Salta y Jujuy (1835-1853)”.

15 Barriera, “Introducción”.

16 Ternavasio, Gobernar la Revolución. Poderes en disputa en el Río de la Plata, 1810-1816, pp. 17-18. 
ticas, al ejercicio del poder y por qué no, a las posteriores propuestas estatales. La especificidad del estudio de caso desde un análisis micro contribuye a enriquecer el abanico de situaciones que presentó la historia de la administración de la Hacienda en América durante el proceso revolucionario. Para el caso de Salta este período no redundó en un cambio drástico en la organización de los guardas de la Aduana, sino que, a pesar del inestable contexto político, siguieron actuando bajo las normativas coloniales.

Para llevar a cabo este trabajo se realizó un barrido sistemático de los heterogéneos Fondos de Gobierno del Archivo y Biblioteca Provincial de Salta donde se encuentra el grueso de la documentación oficial relativa a la Hacienda de la intendencia.

\section{LA POLÍTICA EN SALTA A PRINCIPIOS DEL 1800}

En 1783, con la implementación del Sistema de Intendencias, el virreinato del Río de la Plata de reciente creación fue reorganizado jurisdiccionalmente, y sus gobernaciones divididas en ocho intendencias. Se creó así la Intendencia de Salta del Tucumán, con capital en la ciudad de Salta, que comprendía además las ciudades de Jujuy, San Miguel de Tucumán, Santiago del Estero y Catamarca, con sus respectivas jurisdicciones. El siglo XIX inició con una especial situación de inestabilidad política: el gobernador intendente, Rafael de la Luz, había fallecido en 1807 encargándose del gobierno su teniente asesor Joseph de Medeiros, en tanto que el mando militar había recaído en manos del sargento mayor del regimiento de dragones de milicias, José Francisco Martínez de Tineo. Por los sucesivos viajes que debió emprender Medeiros ocuparon su cargo en calidad de sustitutos el alcalde de primer voto, Tomás Arrigunaga y Archondo y el contador de las Cajas Reales, Nicolás Villacorta y Ocaña. Finalmente, en 1809 el virrey Santiago de Liniers nombró en comisión y provisionalmente para ocupar el cargo de intendente a Nicolás Severo de Isasmendi. ${ }^{17}$

Paralelamente, en el cercano Alto Perú se desarrollaban los movimientos revolucionarios de Chuquisaca y La Paz, los cuales no fueron ajenos para los vecinos de Salta, incluso, según el virrey Cisneros, algunos abogados de la

17 Acevedo, La intendencia de Salta del Tucumán en el virreinato de Río de la Plata, pp. 463 y 464. Isasmendi era uno de los hombres más ricos de la región. Basaba su riqueza en la producción de su hacienda con la cual desarrollaba una intensa actividad mercantil exportando lana de vicuña a España, comercializando jabón y ganado vacuno en el Alto Perú, invernando mulas y abasteciendo de harinas y vino al mercado local y regional. Mata, Tierra y poder en Salta. El noroeste argentino en vísperas de la independencia. 
Intendencia se habían expresado subversivamente contra los intereses reales. $^{18}$

Cuando el cabildo de Buenos Aires se pronunció a favor de la revolución, en su calidad de capital del virreinato pretendió un acatamiento explícito al nuevo gobierno por parte de las autoridades de las ciudades subordinadas. Isasmendi, en un primer momento y presionado, reconoció a la Junta de Buenos Aires, pero a posteriori intentó reducir a los “enemigos de la causa del rey” apoyándose en comerciantes peninsulares y oficiales reales cuya reacción varió entre la ambigüedad y la abierta oposición a la revolución. Desde un principio la facción "realista” contó con un considerable número de adeptos, manifiestos o encubiertos, los necesarios para alentar al ejército del Rey acerca de las posibilidades de poseer esos territorios. ${ }^{19}$

Mientras tanto, desde España se realizaban infructuosos nombramientos para el cargo de Intendente de Salta, ${ }^{20}$ por su parte, el presidente de la Audiencia de Charcas, Vicente Nieto, ordenaba que se enmendara la posición favorable al gobierno revolucionario so pena de hacerles sentir el rigor debido a los traidores. ${ }^{21}$ Finalmente, Isasmendi fue relevado de su cargo por la Junta Provisional de Buenos Aires y en su lugar asumió el auditor de guerra del Ejército Auxiliar: Feliciano Chiclana. ${ }^{22}$

Desatada la guerra desde Buenos Aires contra los focos realistas se imponía la creciente necesidad de reclutar hombres y recursos materiales; para sostenerla se planteó el dilema de cómo generar y mantener adhesiones al nuevo orden en ciudades y regiones alejadas. Las tropas debían proveerse en los espacios convertidos en escenarios de guerra y dicha provisión dependía

19 Mata, "La guerra de independencia en Salta y la emergencia de nuevas relaciones de poder".

20 El 30 de julio de 1810 desde Cádiz se nombró como gobernador intendente político y militar de Salta a don Manuel Ramón por [dimisión] del coronel don Víctor Salcedo y Somodevilla nombrado a raíz del fallecimiento de la Luz. Archivo General de la Nación Argentina (AGN), Sala IX, Nombramientos civiles y eclesiásticos, J-Z. Somodevilla había sido nombrado por la Junta de Sevilla en 1809 y Ramón por el Consejo de Regencia; Acevedo, $L a$ Revolución de Mayo en Salta. Marcela Ternavasio rescata una carta escrita por Domigo Matheu en la que menciona que el Consejo de Regencia daba empleos "a troche y moche" para las Américas. Ternavasio, Gobernar la Revolución. Poderes en disputa en el Río de la Plata, 1810-1816, p. 49.

21 Oficio de Nieto a Isasmendi. Chuquisaca, 11 de julio de 1810. AGN. Archivo de Gobierno de Buenos Aires. Tomo 22. Reproducido en Levene, Ricardo: Ensayo histórico sobre la Revolución de Mayo y Mariano Moreno. Buenos Aires, 1921. Tomo II, p. 387. En Acevedo, La Revolución de Mayo en Salta, p. 165.

22 Isasmendi había pedido en reiteradas oportunidades que lo apartaran del cargo. Chiclana era abogado, porteño, tuvo una importante actuación en todos los sucesos desarrollados en Buenos Aires desde la época de las invasiones inglesas, integraba el elenco de los que habían buscado el cambio de gobierno. Acevedo, La Revolución de Mayo en Salta. 
del consenso que pudiera tener la Junta entre las élites locales. El decreto dictado en febrero de 1811 creando Juntas Provinciales y Subalternas fue un intento de respuesta política a este problema, ${ }^{23}$ por reglamento se erigieron Juntas Principales en cada capital de Intendencia y Juntas Subordinadas en las ciudades y villas. Las Principales estaban integradas por el gobernador intendente y cuatro vocales elegidos por el pueblo y en ellas residía toda la autoridad del gobierno de la provincia, las subordinadas estaban compuestas por el comandante de armas de la ciudad y dos vocales elegidos también por el pueblo. ${ }^{24}$ Luego del intento de gobernar a través de las Juntas lo que siguió vigente en las ciudades del interior fue la ordenanza de intendentes con la unidad de las cuatro causas.

En 1812 Salta fue tomada por los realistas y volvió a manos de los revolucionarios el 20 de febrero de 1813 luego de que las tropas de Belgrano derrotaran al ejército de Pío Tristán en Castañares, al norte de la ciudad. En este punto el Ejército Auxiliar del Perú se acantonó en Jujuy, varios salteños y jujeños que apoyaban la causa del rey, temerosos de las represalias, emigraron a las ciudades altoperuanas, otros permanecieron en Salta trabajando a favor de la corona. En 1814 el ejército realista volvería a entrar en la ciudad al mando del general Pezuela quedándose allí por espacio de seis meses para luego retirarse. En octubre de ese año el Director Supremo de las Provincias Unidas del Río de la Plata, Gervasio Posadas, decretaba la división del territorio creando la provincia de Tucumán. La provincia de Salta quedó entonces conformada por las ciudades de Salta, Jujuy, Orán, Tarija y el Valle de Santa María. ${ }^{25}$ Luego de estos acontecimientos, desde el cuartel instalado en Tupiza, los realistas realizaron varias incursiones sobre Salta en tanto que el ejército Auxiliar sólo avanzaría sobre el Alto Perú en 1816, a su regreso, derrotado por tercera vez, se establecería definitivamente en Tucumán dejando librada la lucha contra los realistas a las fuerzas locales, quienes la sostendrían hasta $1821 .^{26}$

En definitiva, desde la revolución en 1810 hasta 1815, año en que asume Martín Miguel de Güemes, la situación política estuvo enmarcada, como lo mencionamos anteriormente, en un período de gran inestabilidad: diez gobernadores ejercieron sus cargos de manera intermitente, nueve nombrados por el

23 Ternavasio, Gobernar la Revolución. Poderes en disputa en el Río de la Plata, 1810-1816, p. 51.

24 Tío Vallejo, Antiguo Régimen y liberalismo. Tucumán, 1770-1830. Ternavasio, Gobernar la Revolución. Poderes en disputa en el Río de la Plata, 1810-1816. Las juntas se formaban por pares que constituían un órgano de carácter colegiado con iguales funciones, que se vigilaban y custodiaban recíprocamente.

25 Solá, “Salta (1810-1821)”, p. 366.

26 Mata, "Salta y la guerra de la independencia en los Andes Meridionales". 
gobierno de Buenos aires. Sumado a esto, en dos oportunidades, 1812 y 1814, la ciudad fue tomada por el bando realista quedando bajo su jurisdicción.

El control sobre el territorio por parte de la autoridad central en todo este período no fue sólo virtual, sino bastante dudoso. Los ejércitos en los frentes de batalla ejercieron una suerte de autoridad ad hoc mientras las disputas jurisdiccionales entre autoridades capitulares, gobernadores intendentes y comandantes de armas proliferaban. La presencia del Ejército Auxiliar ofreció nuevas alternativas de poder y generó conflictos que además involucraron a los jefes militares locales en la lucha por el poder político y el control de los milicianos.

Durante todo este período el centro de la vida económica en Salta fue el comercio de mulas, principal rubro de exportación entre 1801 y 1810 . Posteriormente, con la revolución, los empréstitos forzosos, las confiscaciones de ganado, la lucha y los éxodos llevaron a la quiebra a importantes hacendados. La guerra sembró ruinas económicas y paralización aunque no el fin del comercio, incluso el intercambio con el enemigo pudo haber alcanzado una dimensión considerable, de hecho existieron denuncias sobre comunicaciones comerciales clandestinas en plena guerra, en especial con referencia a ventas de animales. ${ }^{27}$

\section{EL RESGUARDO DE LA AdUANA}

Salta desempeñaba un papel clave dentro del flujo comercial que conectaba a Buenos Aires con el Perú, constituía el linde de la cuenca rioplatense y última parada posible donde aprestar el ganado para la penosa ascensión a través de las abras. En la última década colonial los ingresos de su Caja mostraban que la mayor recaudación provenía de los impuestos al comercio de entre los cuales, el ramo de sisa encabezaba la lista seguido por el de alcabalas. La sisa se cobraba sobre ciertos productos en tránsito hacia el Alto Perú y el Perú, y se destinaba a la defensa de la frontera Este del Tucumán, si bien el mayor porcentaje de ingresos provenía de los gravámenes sobre el comercio mular, también se extendían sobre productos tales como el aguardiente, el ganado vacuno, la yerba mate y el jabón. La segunda fuente de ingresos provenía del ramo de alcabalas, este gravamen se percibía sobre el valor de todas las mercancías o productos (muebles, inmuebles y semovientes) que se vendían o permutaban en la jurisdicción. Se trataba de un impuesto indirecto que incidía en general sobre los consumidores y que asumía el carácter de una imposición a la circulación, ya que su pago debía efectuarse en el 
momento de introducirse los efectos en el suelo alcabatorio, es decir, al ingresar en la jurisdicción territorial de una administración de alcabala. ${ }^{28}$

Las cajas principales de la Real Hacienda se hallaban ubicadas en la ciudad de Salta desde 1784, allí residían los ministros, tesorero y contador, encargados, entre otras cosas, del control y la recaudación fiscal. Con frecuencia y desde los inicios de la conquista, las cajas reales tenían como anexo almacenes de materiales y ocasionalmente arsenales en los que se guardaban los bienes que pertenecían a la Corona. En Salta, fue recién a fines de 1801, cuando en la capital virreinal se registraba el mayor número de oficiales reales ${ }^{29}$ y dentro del programa borbónico que buscaba una mayor captación del fisco, que se autorizó la creación de un Almacén o Aduana. Esta inversión tardía se justificaba además por la fase de esplendor que atravesaba la saca de mulas hacia el Perú.

En las Aduanas Reales debían presentarse todos los efectos y frutos comerciables para su confrontación con las guías en virtud de la seguridad del derecho de alcabala y otros municipales. Aunque cada año se designaban guardas al comenzar la feria de mulas en el mes de febrero para controlar el pago de la sisa, la creación de la Aduana en Salta, y su correspondiente Resguardo, resultó de fundamental importancia ya que facilitaría el registro sistemático de los efectos que se introducían en la ciudad para que nadie descargara en sus tiendas y posadas particulares y evitar así la segura defraudación al fisco. ${ }^{30}$ Además significaba la existencia de un plantel de guardas permanente ya que hasta ese entonces sólo se designaban guardas de manera temporaria para la feria de mulas. ${ }^{31}$

Como mencionáramos, con el establecimiento del Almacén se nombró a los correspondientes oficiales para su manejo, un Resguardo compuesto por

28 Wayar, “La estructura fiscal de la Intendencia de Salta. 1800-1809.

29 La creación del virreinato del Río de la Plata en 1776 produjo un notable crecimiento de la administración en Buenos Aires y en menor medida en el interior, al momento de su fundación se creó también la Junta de Hacienda, posteriormente, el virrey Pedro de Cevallos y su sucesor establecieron dos ramas adicionales de la Hacienda, la Junta de Diezmos (1777) y la Aduana (1778). Lynch, Administración colonial española el sistema de intendencias en el Virreinato del Río de la Plata; Socolow, The Bureaucrats of Buenos Aires, 1769-1810: Amor al Real Servicio.

30 Aramendi, "En lo más bajo de la administración colonial: guardas y receptores de la Real Hacienda. Salta, siglo XVIII”.

31 Sánchez Albornoz señala que en otoño, cuando todos los mulares de la feria habían sido despachados, el guarda retornaba a Salta y se le labraba un acta certificando el término de sus funciones. Sánchez Albornoz, "La saca de mulas de Salta al Perú, 1778-1808, pp. 287 y 288. Este modus operandis no era extraño, pues la contratación de personal interino se realizaba a todo lo largo del Imperio en ocasiones especiales en que se creía oportuno aumentar la vigilancia. Delgado Ribas, "Fiscalidad y comercio con América: los Resguardos de Rentas de Catalunya (1778-1799)”, p. 82. 
un alcalde de aduana o guarda de almacén, un mayor o comandante, un teniente y tres guardas. El alcalde de la aduana gozaba de fuero militar ya que ante la ausencia de almacén de artillería se le unieron las obligaciones de este empleo. ${ }^{32}$

Resguardo de la Aduana de Salta (1802)

\begin{tabular}{lll}
\hline \multicolumn{1}{c}{ Cargo } & \multicolumn{1}{c}{ Nombre } & \multicolumn{1}{c}{ Sueldo } \\
\hline $\begin{array}{l}\text { Alcalde de Aduana o Guarda } \\
\text { de Almacén }\end{array}$ & $\begin{array}{l}\text { Lorenzo Fernández } \\
\text { Baldivieso }\end{array}$ & 400 pesos anuales \\
Mayor o Comandante & Benito Ortiz de la Torre & 35 pesos mensuales \\
$2^{\circ}$ Guarda o Teniente & Ramón Lagrú & 28 pesos mensuales \\
$3^{\circ}$ Guarda & Gaspar Espinoza & 25 pesos mensuales \\
$4^{\circ}$ Guarda & José Fructuoso González & 20 pesos mensuales \\
$5^{\circ}$ Guarda & Pedro Lagrú & 16 pesos mensuales \\
\hline
\end{tabular}

Fuente: $\quad$ ABHS, Fondos de Gobierno, Caja 20, Año 1802, Carpeta Febrero.

Las funciones generales de los guardas consistían en celar en las entradas a la ciudad toda extracción o introducción clandestina y aprehenderla al hallarla; investigar el por menor de ventas, reventas y cambios de efectos y ganado e informar a los ministros y a los receptores de los curatos rurales para deducir de dichos contratos el derecho de alcabala correspondiente. ${ }^{33}$ Debían asegurarse de que los efectos extraídos, gravados con el impuesto de la sisa, lo hubieran satisfecho. Todo esto debidamente registrado en los cuadernos de cuentas.

Además, estas tareas reglamentarias incluían que cada año, para la época de la feria de mulas, los miembros del Resguardo fueran designados a diferentes parajes estratégicos en el camino hacia el Perú. ${ }^{34}$ Para el cobro de la sisa de mulas en Salta, el tesorero y el contador de la Real Hacienda registraban el nombre del comerciante internador, la cantidad de mulas remitidas $y$, en algunas oportunidades, el destino final y el nombre del tropero que

32 Archivo y Biblioteca Históricos de Salta (en adelante ABHS), Fondos de Gobierno (en adelante FG), Caja 20, Año 1802, Carpeta Febrero. Salta 22 de agosto de 1804.

33 El ramo de alcabalas significaba la segunda fuente de ingresos de la Intendencia, este gravamen se percibía sobre el valor de todas las mercancías o productos (muebles, inmuebles y semovientes) que se vendían o permutaban en la jurisdicción. Wayar, "La estructura fiscal de la Intendencia de Salta. 1800-1809”.

34 ABHS, FG, Caja 20, Año 1802, Carpeta Febrero. Salta 22 de agosto de 1804. ABHS, FG, Caja 27, Año 1810, Carpeta Enero. Salta, 16 de enero de 1810. 
conducía la recua. Una vez realizado este trámite, se emitía una guía que el arriero debía exhibir en los diferentes puestos instalados a la vera de las rutas comerciales. En cada puesto, el guarda era el encargado de controlar si la cantidad de mulas que consignaba la guía coincidía con las mulas en tránsito. Si se detectaba un exceso, el guarda debía cobrar los seis reales correspondientes por cabeza. ${ }^{35}$ La tarea en estos puestos consistía en confrontar las guías, controlar el derecho de alcabala y rastrear en las inmediaciones del puesto en busca de indicios que pudiesen hacer sospechar la extracción de ganado por "veredas extraviadas” con fines de evasión.

Sánchez Albornoz señaló que los cuatro principales resguardos eran la Quebrada del Toro, Piscuno, Los Sauces y La Quiaca. El camino principal de las mulas pasaba por la boca de la Quebrada del Toro, canalizando un tráfico tan grande que, en comparación, el de los demás pasos resultaba insignificante. ${ }^{36} \mathrm{Al}$ poniente de Salta, a unos doce días de marcha, la recua tropezaba con un segundo puesto, el de Piscuno, último resguardo de la Hacienda antes de la internación en el Altiplano. El segundo camino se dirigía hacia el norte y llegaba a Jujuy, y por la Quebrada de Humahuaca a Tarija; entre Salta y Jujuy el puesto de los Sauces abrazaba todo lo que iba y venía por la angostura del Río Blanco y diversos caminos desde Cobos a Perico. El resguardo final estaba situado en La Quiaca, por este cruce pasaban algunos de Salta y buena parte de los de Jujuy. Un tercer paso llevaba por vericuetos desde los valles calchaquíes hasta la Puna, los resguardos eran los de Santa María y Calchaquí; este paso coincide con uno de los tramos de los llamados "Caminos del Despoblado" que ingresando por Coquimbo (Chile) llegaba a la Poma en los valles Calchaquíes y desde allí subía directamente a la Puna. ${ }^{37}$

Las rutas hacia el norte y, sobre todo, los caminos de herradura que articulaban Jujuy con otros espacios eran innumerables, aunque pocos de ellos eran usados para el transporte de animales cargados, pues era necesario que las rutas cumplieran algunos requisitos que garantizaran el arribo de las tropas y las arrias: pasturas, aguadas, y evitar los peligros típicos de la región

35 Wayar, “La estructura fiscal de la Intendencia de Salta. 1800-1809”. Para una descripción acabada del sistema de guías y las rutas comerciales empleadas, véase Sánchez Albornoz, “La Saca de mulas de Salta al Perú, 1778-1808”.

36 Ibíd., p. 287.

37 Sánchez Albornoz supone esta opción como más aparente que real ya que presume que no debieron ser muchos los animales sometidos a la fatiga de subir directamente desde los valles hasta la Puna. Sánchez Albornoz, “La saca de mulas de Salta al Perú, 1778-1808”, p. 286. Assadourian y Palomeque, "Los circuitos mercantiles del "interior argentino" y sus transformaciones durante la Guerra de la Independencia (1810-1825)”. 


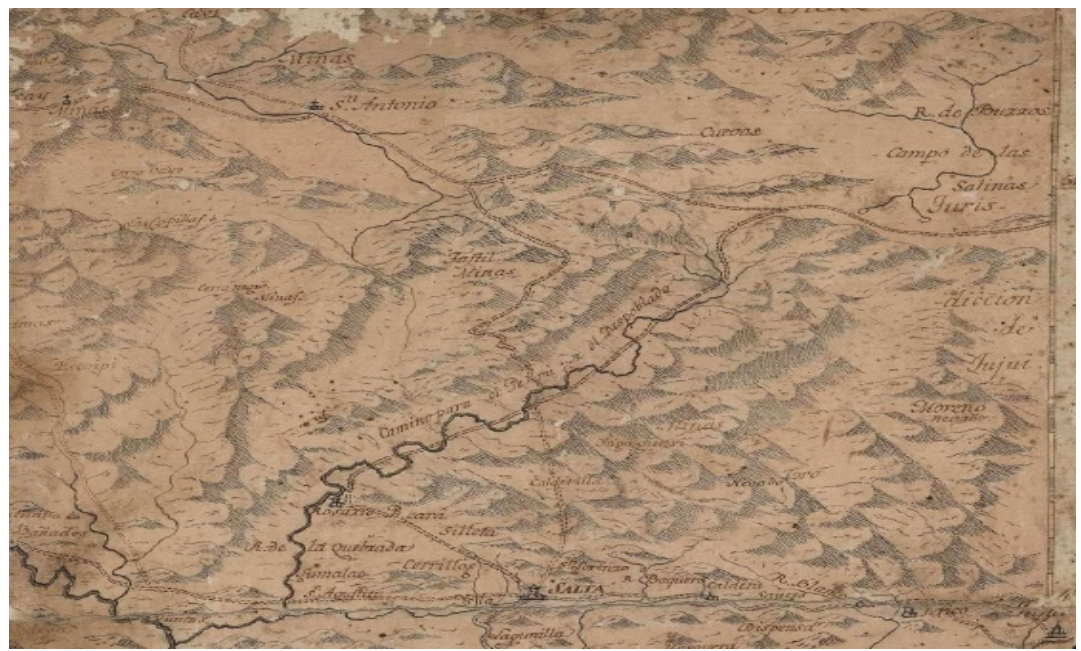

Figura 1. LARRAMENDI. Mapa de La Jurisdicción de Salta. Detalle [17--]. 1 mapa ms, desenho a tinta nanquim, 40,8 x 34 cm em f. 42,28 x 37. Disponível em http://acervo.bndigital.bn.br:8080/jspui/handle/123456789/219, acesso em: 18 novenmbro, 2019.

como los “malos pasos” y los desmoronamientos. ${ }^{38}$ Sánchez Albornoz afirma que debido a la accidentada topografía, los pasos eran pocos y la custodia fácil, pero al mismo tiempo expone que en la documentación, como lo señalamos más arriba, se enuncia la existencia de "veredas y caminos extraviados” por los cuales se podía llevar la hacienda que no tuviera despachos legítimos. $^{39}$

A la par del establecimiento del Resguardo se nombraron guardas, dos en Jujuy, uno en Tucumán y otro en Santiago del Estero. ${ }^{40}$ Según las Instrucciones el guarda mayor de Jujuy debía permanecer constantemente en la ciudad, pero su segundo debía fijar su residencia por el tiempo que durara la feria de mulas y vacas en Humahuaca. ${ }^{41}$ Previo a la creación del Resguardo, Sánchez Albornoz señala que los guardas designados de manera temporal

Conti y Sica, “Arrieros andinos de la colonia a la independencia. El negocio de la arriería en Jujuy, Noroeste Argentino".

39 Archivo General de la Nación Argentina, Sala XIII, 9-9-1, Libro 6. Tesorería de Salta, 19 de febrero de 1790. Citado en Sánchez Albornoz, "La saca de mulas de Salta al Perú, 17781808 ”, p. 305.

40 ABHS, FG, Caja 20, Año 1802, Carpeta Febrero. Buenos Aires, 18 de noviembre de 1799.

41 Ibíd. Salta, 22 de agosto de 1804. 
para celar los pasos durante la feria de mulas eran gente de posición social desahogada y gozaban de un buen sueldo, entre ellos figuraban el mencionado Benito Ortíz de la Torre y Domingo Puch, comerciante de mulas. No creemos que esa haya sido la extracción social de todos los miembros del Resguardo, al parecer, salvo el alcalde y el comandante, se trataba de españoles pobres, algunos con cierta actividad comercial. Cuando se dieron las instrucciones para nombrar a los guardas se instruyó a los ministros de Salta para que propusieran “sujetos españoles” que supieran escribir regularmente. ${ }^{42}$

La mayoría de los oficiales nombrados para conformar el flamante Resguardo de la Aduana ya formaban parte del aparato administrativo como empleados de la Hacienda y cabe mencionar que por lo menos dos de ellos probablemente ejercían actividades comerciales: el mencionado Ortíz de la Torre y Ramón Lagrú.

Al momento de nombrar un nuevo miembro del Resguardo en la primera década del 1800, fue un miliciano el elegido. En 1808, ante el fallecimiento del comandante, los ministros de Hacienda propusieron el ascenso de todos los oficiales y el nombramiento, como $5^{\circ}$ guarda del primogénito de Ortíz de la Torre. El gobernador Rafael de la Luz aprobó esta decisión, pero el virrey Liniers nombró para el cargo vacante a Ángel Vicente Sánchez en atención a sus calidades y a los méritos contraídos en el servicio de las milicias de la ciudad. ${ }^{43}$

El ingreso de milicianos a la administración debe ser analizado en el especial momento histórico que atravesaba la región, aunque no era la primera vez que un miliciano era nombrado para la tarea de celar puestos en la feria de mulas y vacas. ${ }^{44}$ Paralelo al contexto de militarización de la monarquía en el siglo XVIII podemos señalar la militarización de la sociedad dada sobre todo en la segunda mitad del siglo en los Andes surandinos. En 1803 se organizaron las milicias que instalaron la presencia de hombres armados de distinta condición social, encabezadas por hacendados y estancieros, que instalados desde siempre en el poder local, devenían ahora en jefes milicia-

42 ABHS, FG, Caja 20, Año 1802, Carpeta Febrero. Tesorería de Salta, 20 de julio de 1804.

43 En 1797 Sánchez había sido nombrado como ayudante mayor de la plaza con un sueldo de 300 pesos a cobrar del Real Erario y 360 cobraderos de la sisa. ABHS, FG, Caja 20, Año 1802, Carpeta Agosto. Salta, 31 de agosto de 1802.

44 En 1793 era un soldado quien celaba el puesto de Laparca o Ingahuasi. ABHS, FG, Caja 14, Año 1793, Carpeta: Borrador de una nota de la tesorería de Salta al comisionado Juan Cenarrusa para que cambien al soldado puesto en el recuento de mulas. Salta, 19 de febrero de 1793. En 1789 el gobernador Pizarro nombró al teniente de milicias, Gaspar Arias, para celar el puesto de Piscuno. ABHS, FG, Caja 16 A, Años 1797-1799, Carpeta sin asunto. Salta, 8 de enero de 1797. 
nos con potestad de administrar justicia y con un creciente poder político. En 1811 se habían organizado ya ocho compañías, siete de las cuales correspondían a partidos rurales de la jurisdicción de la ciudad de Salta. ${ }^{45}$

Cabe preguntarse por qué el virrey, la más alta autoridad administrativa y política de la jurisdicción, decidió el nombramiento de un guarda de la Aduana de Salta. Si bien los guardas constituían un instrumento de ejecución clave de la política estatal en materia de recaudación se acostumbraba que la propuesta de los nombramientos estuviese en mano de sus superiores inmediatos.

Ángel Vicente Sánchez recibía como ayudante mayor de la plaza un mejor estipendio más alto que el que percibió como miembro del Resguardo. Aquí se plantea entonces como una hipótesis plausible que el Resguardo funcionó -en este caso- como un lugar de retiro para el miliciano. De todas maneras debemos decir que Sánchez no era uno más entre tantos, en 1810 el cabildo lo había convocado para la elección del diputado que representaría a Salta en Buenos Aires dentro del grupo catalogado como "Noble Vecindario” donde figuraba solamente el nombre de treinta personas. ${ }^{46}$

\section{LA MOVILIDAD DE LOS GUARDAS EN EL PROCESO REVOLUCIONARIO}

Acaecida la revolución, nos interesa reflejar cómo continuó la vida profesional de los guardas. En los primeros años se perdió el control de los centros mineros, la producción de plata colapsó entre 1812 y 1815, del antiguo tráfico quedaron entonces algunos envíos irregulares, muchos por el camino del Despoblado. Dentro de este contexto general se dieron relaciones puntuales con los dichos centros mineros signadas por las circunstancias políticas, cuando las tropas del Ejército revolucionario consiguieron controlar Potosí: septiembre de 1810 a junio de 1811 , febrero a noviembre de 1813 y abril a noviembre de 1815, momento a partir del cual empeora la situación mercantil. ${ }^{47}$

45 Los hacendados y estancieros criollos ascendieron a los grados de coroneles y capitanes de las milicias y se enfrentaron a los funcionarios borbónicos ya que por la implementación del Reglamento de Milicias de 1805 sustraían de la justicia ordinaria a peones, pequeños propietarios y arrenderos devenidos en milicianos. Mata, S: "Salta y la guerra de la independencia en los Andes Meridionales".

46 AGN, Archivo de Gobierno de Buenos Aires, tomo 21. Citado en Acevedo, La Revolución de Mayo en Salta, p. 101. La elección de las personas que conformaron ese "noble vecindario" seguramente fue determinada por su posición política de apoyo a los capitulares frente al conflicto con el gobernador Isasmendi pero también es cierto que se trataba de un grupo identificado con "la parte más sana del pueblo”. Ibíd., p. 105.

47 Assadourian y Palomeque, “Los circuitos mercantiles del 'interior argentino' y sus transformaciones durante la Guerra de la Independencia (1810-1825)”, pp. 64 y 65. 
El único reemplazo por el cual ingresó a las filas del resguardo una persona ajena al departamento de Hacienda fue el que se dio ante el fallecimiento del teniente Ramón Lagrú en 1811. El nombramiento recayó en el miliciano Francisco Reyna, designado por el gobernador de Salta, Feliciano Chiclana, en atención a su servicio a la patria: ${ }^{48}$ "“[...] en el que se expuso a perder la vida [...], en condigno premio y remuneración de su distinguido merito hasta la resolución de la Excelentísima Junta Superior [...]”. ${ }^{49}$

Los ministros de la Hacienda expresaron su malestar frente a un nombramiento que no respetaba las graduaciones, refirieron que los sueldos del Resguardo eran muy bajos y que la única dicha para ellos estaba dada por el ascenso. ${ }^{50}$ Esta posición se basaba además en las formas de administración que desde la segunda mitad del siglo XVIII habían querido implantar un escalafón graduado y jerarquizado donde lo corriente fuera ascender puesto por puesto. Una real cédula de 1761 especificaba que la antigüedad era el primer criterio para el ascenso, inclusive más importante que el mérito. ${ }^{51}$ Estaba implícita la queja además por la vulneración al derecho a nombrar a sus subalternos, por los cuales debían responder. ${ }^{52}$ La postura de los ministros fue desoída, Reyna permaneció en su cargo e, incluso, en 1818 fue ascendido pasando a ocupar el lugar de comandante del Resguardo. ${ }^{53}$

Otros cambios dieron marchas y contramarchas, como en el caso del alcalde de la aduana, Lorenzo Fernández Baldivieso. Hacia 1812, en el contexto de la ocupación de Salta por parte del ejército realista, al igual que el resto de sus colegas, Fernández Baldivieso mantuvo su cargo y se pronunció a favor del gobierno revolucionario, incluso donó la mitad de su salario "[...] por el tiempo que dure la temeraria, rivalidad del sanguinario y ambicioso Goyeneche [...]" ${ }^{54}$ En noviembre de 1813 fue nombrado como oficial

${ }^{48}$ ABHS, FG, Caja 20, Año 1802, Carpeta: Febrero. Salta, 16 de enero de 1811.

49 Ibíd. Salta, 21 de septiembre de 1810. En las Instrucciones reservadas que Chiclana dejó a su sucesor en el gobierno de Salta, en el punto que trata sobre los empleos públicos, aconseja no descuidar elevar al "criollaje”. No sabemos a qué empleos se refiere pero podemos pensar esta idea como un objetivo general a llevar adelante. Solá, "Salta (1810-1821), p. 378.

50 ABHS, FG, Caja 20, Año 1802, Carpeta: Febrero. Salta, 16 de enero de 1811.

51 Arnold, Burocracia y burócratas en México, 1742-1835.

52 Bertrand señala el caso de Veracruz en la primera mitad del siglo XVIII donde la selección y contratación de los subalternos y auxiliares fue un tema de fricción entre virreyes y oficiales reales, éstos se sometieron de muy mala gana a los nombramientos realizados por el virrey ya que exigían ser ellos quienes nombraran a sus subordinados lo cual les otorgaba una garantía respecto de la competencia de los subordinados y sobre todo el fortalecimiento de su autoridad. Bertrand, Grandeza y miseria del oficio. Los oficiales de la Real Hacienda de la Nueva España, siglos XVII у XVIII, p. 119.

53 ABHS, FG, Caja 35, Años 1817-1818, Carpeta Febrero. Salta, 24 de febrero de 1818.

54 ABHS, FG, Caja 28 A, Año 1811, Carpeta: Agosto. Jujuy, 17 de agosto de 1812. 
primero de la Hacienda, cargo que anhelaba ocupar desde años atrás, en lugar de Antonio Atienza quien había sido separado del mismo por su condición de peninsular. ${ }^{55}$ El contador, Nicolás Villacorta y Ocaña, no estuvo de acuerdo con esa disposición:

Por más que el Excelentísimo Superior Gobierno se afane, y desvele en proveer los empleos en personas de aptitud, y honor, a la distancia, no es difícil padecer un equiboco. Asi ha sucedido con el empleo de oficial primero de estas cajas. Puede Vuestra Señoría venir el día que guste venir a la oficina, y palpará hasta donde se extienden los conocimientos de Baldiviezo: El ultimo del mes próximo pasado, le encargué hiciese el ajuste del sueldo que me correspondía, [...] despues de un gran rato, le fue preciso confesarme que no lo entendia, y que no podia formarlo. [...] Me duelo de la suerte de Baldivieso; pero la salud publica, y el bien del Estado es el primer objeto de mi inclinación. Estoy cierto que la destreza y pureza en el manejo y administracion de la hazienda nacional, es demasiado interesante a todo estado por mas opulento que sea por consiguiente al nuestro, que empieza a ser [...]”. ${ }^{56}$

En esta ocasión las observaciones de quien llevaba años desempeñándose en el servicio de la Hacienda fueron atendidas, se autorizó el reingreso de Atienza al ejercicio de las funciones que desempeñaba, pero sin investidura alguna y Fernández de Baldivieso fue jubilado. ${ }^{57}$

El siguiente dato que tenemos sobre el cargo de comandante del Resguardo es que en 1815 lo ocupaba Gaspar Salvador Arias ${ }^{58}$ quien, siendo teniente de milicias, en 1795 y 1796 había celado la Quebrada del Toro y en 1799 el puesto de Piscuno. ${ }^{59}$

En la revolución encontramos ciertos recambios en relación a los guardas, pero que no estuvieron determinados por ese proceso político, sino por causas más rutinarias como jubilaciones y fallecimientos. Tal el caso de los guardas de Jujuy, Pedro de la Vega y Francisco Alvarado, quienes en 1811

55 Ya en 1810 Fernández de Baldivieso había solicitado formalmente que se lo nombrara como oficial primero. Aramendi, "En lo más bajo de la administración colonial: guardas y receptores de la Real Hacienda. Salta, siglo XVIII”.

56 ABHS, FG, Caja 30 A, Año 1813; Carpeta: Noviembre. Salta, 5 de noviembre de 1813.

57 Fernández de Baldivieso fue jubilado con las dos terceras partes de su sueldo de quinientos pesos. ABHS, FG, Caja 30 A, Año 1813; Carpeta: Noviembre. Salta, 17 de diciembre de 1813. El de Atienza no fue el único caso de un empleado separado del cargo por su condición de peninsular. El guarda celador de Santiago del Estero, José de Olaechea, fue excluido del goce de su empleo y sueldo por ser europeo español, pero se solicitó que le dieran la ciudadanía. ABHS, Fondos de Gobierno, Caja 30 C, Año 1813. Carpeta: Mayo. Santiago del Estero, 8 de mayo de 1813.

58 ABHS, FG, Caja 32 B, Año 1815, Carpeta: Diciembre. Pucará, 29 de diciembre de 1815.

59 ABHS, FG, Caja 16 A, Años 1797-99. Carpeta sin asunto. Salta, 8 de enero de 1797. 
tenían 70 y 75 años, respectivamente, y habían solicitado su retiro. En ese año el gobernador Isasmendi hizo el pedido para que se los jubilase con medio sueldo de su dotación; ${ }^{60}$ la respuesta fue el nombramiento de sustitutos retribuidos con parte de los sueldos de los guardas propietarios. ${ }^{61}$ Así, el 1 de febrero de 1811 se nombró a Pascual Portal como guarda sustituto de Pedro de la Vega:

“[...] por quanto la avanzada edad y achaques del guarda primero de Jujuy don Pedro de la Vega no le permiten hacer el servicio activo que se necesita [...] nombramos por guarda sobstituto de dicho Vega a don Pasqual Portal sujeto en quien concurren las calidades necesarias para ello, con el sueldo mensual de catorce pesos pagaderos del que disfruta el mencionado don Pedro [...]”62

En 1812 el teniente tesorero de Jujuy informó sobre la muerte de Francisco Alvarado y mencionó que de la Vega estaba “[...] tan viejo y enfermo que no está para nada [...]”. ${ }^{63}$ Para cubrir el empleo los ministros propusieron, en primer lugar, a Francisco Menendez, quien a mérito había servido en las cajas de Jujuy y el nombramiento fue aprobado por la Junta de Salta. ${ }^{64}$ Además había formado parte de las milicias puesto que lo encontramos presentándose a revista a lo largo de 1802 .

También se dieron ascensos temporarios para salvar imprevistos. En 1814 encontramos al guarda Gaspar Espinosa ocupando el cargo de teniente tesorero de Jujuy ${ }^{65}$ mientras que años después, en 1817, se desempeñaba como guarda mayor en la misma ciudad recaudando los ramos del "ingreso nacional”. ${ }^{66}$

En esta línea de reemplazos temporarios es interesante mencionar que hacia 1811 Espinosa se encontraba enfermo y se designó a su hermano Bal-

60 ABHS, FG, Caja 27, 1810. Carpeta: Enero. Jujuy, 22 de enero de 1811. De la Vega y Alvarado fueron nombrados en 1799 con una dotación de 300 y 250 pesos anuales como guarda primero y guarda segundo, respectivamente. ABHS, FG, Caja 20, año 1802. Carpeta: Febrero. Buenos Aires, 18 de noviembre de 1799.

61 Sustituto, “El que hace las veces de otro en algun empleo ó comisión”. RAE 1817. http://web.frl.es/ntllet/SrvltGUILoginNtlletPub.

62 ABHS, FG, Caja 28 A, año 1811. Carpeta: Julio. Salta, 1 de febrero de 1811.

63 ABHS, FG, Caja 20, Año 1802. Carpeta: Febrero. Jujuy, 6 de enero de 1802.

64 En segundo lugar, los ministros habían propuesto a Pedro Ortíz Martínez hijo de Benito Ortiz de la Torre. ABHS, FG, Caja 20, Año 1802, Carpeta: Febrero. Salta, 9 de enero de 1812.

65 ABHS, FG, Caja 31 A, Año 1814, Carpeta: Noviembre. Jujuy, 1 de noviembre de 1814.

66 Espinosa se quedó en Jujuy ya que cuando tuvo que entregar la caja al nuevo teniente tesorero se dirigió al ministro de Salta, Pedro Antonio de Cevallos solicitando lo dejara servir en esa ciudad. ABHS, FG, Caja 34, Año 1817, Carpeta: Junio. Miraflores, 10 de junio de 1817. 
tasar para celar el puesto de León en la época de la feria de mulas y vacas. ${ }^{67}$ Después se menciona que pasó a León, sin perjuicio de Espinosa, don José Simeón Martínez, receptor de alcabalas de Salta. ${ }^{68}$ Martínez se desempeñaba como receptor desde 1808, en 1810 y frente a los sucesos de mayo, lo encontramos en el grupo de personas que el cabildo dejó fuera para la elección del diputado, es decir, el grupo que no encajaba dentro de "la gente más sana”. ${ }^{69}$ Por dos años consecutivos celó en la feria los puestos de la Quebrada del Toro y León costeando de sus expensas dos mozos, uno para que cele la vereda de Ingaguasi con un salario de cinco pesos por mes durante cuatro meses y el otro para su custodia y ayuda. En su empleo de receptor dejó por este período a otro sustituto sin que se le hiciera abono de gasto alguno ni gratificación. Asimismo, costeó de su peculio un guarda caminero en el paraje de Escoipe y ayudó a hacer el trabajo de pluma en la Real Hacienda. ${ }^{70}$ Como mencionamos, Martínez era el receptor de alcabalas de la ciudad de Salta, los receptores se dedicaban al cobro de dicho gravamen en ciudades y parajes alejados, respondían a los tenientes o a los ministros según correspondiera, no había alcabaleros en todos los parajes, sino sólo en aquéllos donde el comercio tenía un giro importante; por sus tareas les correspondía el $6 \%$ de lo recaudado. La eficacia del oficio estaba en duda, pocos eran los candidatos a realizar esas tareas y muchos los sospechados de dedicarse a la actividad comercial. ${ }^{71}$

Tampoco el ingreso temporal de las fuerzas realistas generó grandes cambios. Cuando Pío Tristán tomó Jujuy, dispuso que se pusieran en funciones los guardas y de no ser posible que Ignacio Guerrico, el teniente tesorero propietario, nombrara a los que creyera conveniente. ${ }^{72}$

Vemos a partir de la descripción de este grupo un rasgo central que caracteriza a la institución y su funcionamiento. Nos referimos a la permanencia en sus puestos de quienes venían formando parte del sistema como empleados de la Hacienda, como miembros de la aduana, como guardas o

67 ABHS, FG, Caja 28 B, Año 1811, Carpeta: Guías libradas que no han tenido tornaguía. Salta, 27 de enero de 1811.

68 Ibíd., Carpeta: Mayo. Salta, 5 de febrero de 1811. No sabemos desde cuándo Martínez ocupaba el cargo de alcabalero en Salta, pero lo desempeñaba desde antes del estallido revolucionario. ABHS, FG, Caja 26, Año 1809, Carpeta: Mayo. Salta, 7 de mayo de 1809.

69 Memorial presentado por varios vecinos de Salta. Sala capitular, 25 de junio de 1810. AGN, Archivo de Gobierno de Buenos Aires, Tomo 21. Citado por Acevedo, La Revolución de Mayo en Salta, p. 110.

70 Ibíd., Caja 29, Año 1812, Carpeta: Marzo. Salta, 26 de febrero de 1812.

71 Aramendi, “En lo más bajo de la administración colonial: guardas y receptores de la Real Hacienda. Salta, siglo XVIII”.

72 ABHS, FG, Caja 29 A, Año 1812, Carpeta: Hojas sueltas. Jujuy, 10 de septiembre de 1812. 
como alcabaleros, independientemente de sus simpatías políticas. ${ }^{73}$ Observamos que las personas que dejaban de ejercer sus funciones eran sustituidas por quienes ya se encontraban incluidos en el sistema administrativo de una manera u otra. Si bien los guardas Gaspar Arias y Francisco Menendez pertenecieron a las milicias y fueron ascendidos en este período, eso se debió a sus carreras dentro de la Hacienda y no a su calidad de milicianos. ${ }^{74}$ El único caso de un ingreso de alguien ajeno al departamento fue el de Reyna.

\section{Resguardo de la Aduana de Salta (1813)}

\begin{tabular}{|c|c|c|}
\hline Cargo & Nombre & Sueldo \\
\hline $\begin{array}{l}\text { Alcalde de Aduana o } \\
\text { Guarda de Almacén }\end{array}$ & Lorenzo Fernández Baldivieso & $\dot{\imath}$ \\
\hline Mayor o Comandante & Ángel Vicente Sánchez (miliciano) & 420 pesos anuales \\
\hline Teniente Comandante & Francisco Reyna (miliciano) & $\dot{\imath}$ \\
\hline $1^{\circ}$ Guarda & Gaspar Espinoza & 300 pesos anuales \\
\hline $2^{\circ}$ Guarda & José Fructuoso González & 240 pesos anuales \\
\hline $3^{\circ}$ Guarda & Pedro Lagrú & $\dot{\imath}$ \\
\hline
\end{tabular}

Cuadro construido con los datos que se detallan en el presente trabajo, tomados de los Fondos de Gobierno del ABHS.

\section{LOS ENFRENTAMIENTOS, ENTRE ANTIGUAS RENCILLAS Y NUEVAS ARENAS DE LUCHA}

Si el período colonial estuvo signado por conflictos entre los distintos representantes de la administración real y local, durante la revolución, éstos se resignificaron e incluyeron a nuevos actores.

Surgieron enfrentamientos al calor de la erección de las nuevas instituciones, como fue el caso de las Juntas. En marzo de 1812 la Junta de Jujuy impidió la salida del guarda $2^{\circ}$ Francisco Menéndez hacia el puesto de León. ${ }^{75}$ Como mencionáramos con anterioridad, cada año para la feria de

73 El 10 de julio de 1810 un grupo de vecinos de Salta elevó una representación al intendente contra el posible retorno de Medeiros, Acevedo colige que los firmantes de ese escrito pertenecían al partido de Isasmendi, entre ellos figuran Ramón Lagrú, Lorenzo Fernández Baldivieso y José Simeón Martínez. Acevedo, La Revolución de Mayo en Salta.

74 Cuando en 1804 los ministros propusieron a Arias para formar parte del Resguardo lo hicieron por ser éste "vecino noble de buena letra”. ABHS, FG, Caja 20, Año 1802, Carpeta: Febrero. Salta, 24 de septiembre de 1804.

75 Aramendi, "Un funcionario en la revolución: postulados presentistas y un estudio de caso de la Real Hacienda en Jujuy”. 
mulas, se designaban guardas en diferentes parajes estratégicos, ${ }^{76}$ en las vías de acceso más usadas estaban establecidas las receptorías aduaneras dependientes de la Aduana de Jujuy, principal fuente recaudadora de divisas. ${ }^{77} \mathrm{La}$ situación de Jujuy era particular ya que era la última ciudad de importancia de la vía carretera del camino Real entre el Río de La Plata y Potosí, en adelante el camino era de herradura, por lo cual el viaje sólo se podía continuar en mula y las mercancías debían enfardarse para ubicarlas en tercios de mula o burro. Dada su situación de centro de tránsito obligado entre la Altiplanicie y las tierras bajas pampeanas, los viajeros permanecían allí el tiempo necesario para equiparse con sus bastimentos, lo cual le imprimía un gran dinamismo mercantil. ${ }^{78}$

La Junta de Jujuy tomó la decisión de frenar la partida del guarda basada en la impracticabilidad del comercio en el momento y se notificó al teniente tesorero en los siguientes términos: "La internación o feria de mulas es impracticable en el dia, interin no mejore de aspecto o tome otro semblante la causa, por cuio motivo no halla por conveniente este gobierno camine el guarda [...]". ${ }^{79}$ Dicha decisión fue tomada en el marco del enfrentamiento entre el órgano de gobierno de la ciudad y el teniente tesorero, Joseph Ignacio de Guerrico, quien dependía directamente de los ministros de Salta. ${ }^{80}$ Guerrico escribió a éstos para dejar sentado su parecer sobre las decisiones de la Junta y no ahorró las apreciaciones que los miembros de la misma le merecían, calificándolos de antojadizos, caprichosos y mandones. ${ }^{81}$ Los ministros decidieron acudir al Prefecto, Pedro José de Saravia, a la sazón gobernador, para que resolviera.

Otro problema que continuaba planteándose en el tiempo fue el relativo a cuestiones jurisdiccionales en tensión entre las ciudades de Salta y Jujuy. Tal es el caso de los mencionados guardas Pedro de la Vega y Francisco Alvarado, quienes en 1811 informaban que no estaban dispuestos a celar los puertos de Piscuno y Quebrada del Toro porque ésos pertenecían a la jurisdicción de Salta y ellos alegaban que habían sido nombrados para servir en el res-

76 Aramendi, “En lo más bajo de la administración colonial: guardas y receptores de la Real Hacienda. Salta, siglo XVIII”.

77 Conti, “Jujuy en 1810”. Cuando en 1784 la Real Hacienda fue trasladada desde Jujuy a Salta, Jujuy conservó la Aduana debido a su estratégica posición en el camino del Alto Perú al Río de la Plata.

78 Conti señala que las guerras de independencia representaron un duro golpe para la economía jujeña, pero debemos mencionar que no se trató del final del circuito comercial, sino más bien de una disminución del flujo dentro del mismo. "Jujuy en 1810”.

79 ABHS, FG, Caja 29, Año 1812, Carpeta: Marzo. Jujuy, 22 de marzo de 1812.

${ }^{80}$ Aramendi, "Un funcionario en la revolución. Postulados presentistas y un estudio de caso de la real hacienda en Jujuy”.

81 ABHS, FG, Caja 29, Año 1812, Carpeta: Marzo. Jujuy, 22 de marzo de 1812. 
guardo de Jujuy. Ignoramos cuál fue el verdadero sentido de ese reclamo, la Quebrada de Toro era el puesto más transitado y por lo tanto, requería mayor trabajo, e igual que Piscuno se ubicaban a una gran distancia de la ciudad de Jujuy. Podemos colegir que dicho pedido fue representativo de las problemáticas jurisdiccionales mencionadas. Salta y Jujuy atravesaron diferentes momentos de conflicto, espaciales, económicos y políticos; en principio los problemas de la delimitación de la jurisdicción de ambas ciudades se pusieron de manifiesto en la superposición de espacios asignados a cada una, así como conflictos por la posesión de encomiendas. Estas situaciones generaron históricas disputas entre los cabildos de ambas ciudades que con la implementación del Sistema de Intendencias se agudizaron a raíz del lugar de subordinación que le tocó ocupar a Jujuy. Medidas que la afectaban directamente quedaban supeditadas a las decisiones de los oficiales reales residentes en Salta. ${ }^{82}$ La historiografía reconoce que al interior de los conflictos suscitados entre ambas ciudades la cuestión arancelaria ocupó un lugar de privilegio, así en el contexto de la creación de las Juntas Provinciales, resurgieron los problemas relacionados a la pretendida autonomía de la ciudad de Jujuy que tomaba medidas de gobierno por cuenta propia y se dirigía directamente a la Junta de Buenos Aires. ${ }^{83}$

Los problemas de la administración que hasta aquí mencionamos estuvieron cruzados por diferentes variables: conflictos personales, jurisdiccionales y políticos. Dos son los escenarios sobre los cuales se erigieron: el conflicto de la guerra y la intención autonómica de los jujeños.

\section{LA “EFICIENCIA” EN EL CONTROL}

Meses antes de proclamada la revolución en Buenos Aires los ministros de Salta expresaban preocupación por la decadencia del ramo de mulas observada en la feria de 1809 con respecto a la del año anterior. Pudieron ser varias las causas de esa disminución, pero estaban seguros de que principalmente se debía a la falta de celo a la hora de resguardar los puestos, especialmente el de Piscuno:

Barias causas pudieron influir para aquella baja; pero en lo fértil del año corriente solo la falta de celo en resguardar los puestos respectivos y con especialidad el importante de Psicuno, recaladero de las principales salidas y el no

82 Costa, “La élite jujeña a fines del período colonial. Gobernaciones Intendencias, pérdidas de privilegios y usos de la justicia (Argentina, siglos XVIII-XIX).

83 Solá, “Salta (1810-1821)”, p. 379. 
hacer las diligencias de registro con la devida exactitud podrán numerarse por las más preferentes. ${ }^{84}$

Sánchez Albornoz ha señalado que la recaudación en 1808 fue particular puesto que se hicieron cobranzas atrasadas con lo cual esto explicaría en parte la decadencia señalada por los ministros para el siguiente año. Sin embargo, es importante no desmerecer sus apreciaciones y destacar que pusieron la mirada en la falta de eficiencia en la recaudación, sobre todo, en Piscuno. ${ }^{85}$

A pesar de la preocupación expresada por los ministros, un año después, el comandante del Resguardo, Ángel Vicente Sánchez, le recordaba al contador Antonio Atienza que en su momento se le abonaba 70 pesos al celador destinado temporalmente a Piscuno y se ponía a su disposición cuatro peones con la ración correspondiente mientras que en ese momento "se ha querido ahorrar tanto que se pierde los más por lo menos”, y señalaba que su sueldo, de 35 pesos, era muy limitado.

Además, Sánchez sentaba el hecho de que la solución para tener un mejor control sobre el cobro de los impuestos correspondientes no recalaba sólo sobre Piscuno:

Las mulas, y las demas especies, que adeudan alcabala y sisa no solamente salen por Piscuno, sino también por Calahoya, Berque, Sancarí y La Quiaca: por consiguiente se necesitan sinco personas y todas fieles, e invencibles para evitar extracciones clandestinas [...] que acaso no se podrá conseguir, que los dueños o capataces de las haciendas extraidas se personen todos en un punto, y es imposible que yo, ni alguno de mis subalternos estemos simultáneamente en todos. ${ }^{86}$

El escrito de Sánchez ocasionó una dura respuesta por parte de Atienza en relación a la falta de experiencia de aquél en su nueva calidad de oficial administrativo y le ordenó:

[...] cubra vuestra merced con un dependiente el paso de la Quiaca, y cele con los otros dos el de Piscuno, pues ambos son los importantes con distintos respectos, y no medite acerca de los cinco peones que en lo pasado se concedían al guarda temporal de este ultimo punto para celar, por que aunque a todos los un ojo de agua, único en la circunferencia de muchas leguas. Además encontró allí la receptoría de la sal (y a su respectivo receptor) donde la gente que sacaba sal del lugar pagaba el derecho de un real por carga. Brackebusch, Por los caminos del Norte, p. 45. 
pagaba la sisa, muchas veces fue dudosa o incierta para varios del publico su existencia. ${ }^{87}$

Los dichos de Atienza revisten una gravedad alarmante, pues ponen en duda la existencia de los peones ayudantes del guarda. En un puesto tan concurrido por donde se suponía pasaba la mayor parte de las recuas hacia el Alto Perú y que demandaba un control especial asegura que no puede afirmar la existencia de los cinco dependientes. ${ }^{88}$

Además de estos hechos particulares cabe preguntarse sobre cuál era la capacidad que tenían los guardas para vigilar, perseguir y evitar evasiones. Es notable que los guardas se mantenían en su oficio sin importar la edad que tuvieran y si padecían alguna enfermedad o incapacidad. ${ }^{89}$

Finalmente, podemos mencionar aquí, que desde la colonia se ponía en duda la fidelidad y el celo de los guardas, sospecha que puede haberse extendido en el tiempo. ${ }^{90}$ Algunos de ellos fueron acusados de tener pulperías, otros sospechados de ser comerciantes o estar vinculados a ellos, lo cual implicaba una flagrante contradicción entre los intereses personales de esos guardas y los intereses de la Hacienda al convertirse en individuos pasibles de pagar los mismos impuestos que estaban obligados a cobrar. Una contradicción y una oportunidad económica para quienes desempeñaran el cargo.

Observamos en relación a esa desconfianza que sobrevolaba a los guardas que en 1804, el teniente de Tucumán demoraba la tarea de elegir uno porque no encontraba sujetos a su satisfacción “[...] pues aunque a los principios todos son hombres buenos al poco tiempo se hacen malos”. ${ }^{91}$

\section{EL PROBLEMA DE LOS SUELDOS}

87 Ibíd., 1 de febrero de 1810. En relación a La Quiaca, Brackebusch señalaba: "Seguimos el límite con Bolivia y pasamos la noche en la aduana de La Quiaca, donde nos hicieron decir de qué manera puede ser que en estas soledades no haya más contrabando.” Brackebusch, Por los caminos del Norte, pp. 53-54.

88 En 1790 consta la existencia de cinco peones que ayudaron en sus tareas a Benito Ortíz de la Torre en su calidad de guarda en la Boca de la Quebrada del Toro. Sánchez Albornoz "La saca de mulas de Salta al Perú, 1778-1808”, p. 287. Los peones fueron contratados por Ortiz de la Torre.

89 En 1810 Ramón Lagrú señalaba que se hallaba ciego por su avanzada edad y los rigores del tiempo sufridos en La Quiaca. ABHS, FG, Caja 27, Año 1810, Carpeta Enero. Purmamarca, 30 de mayo de 1810.

90 ABHS, FG, Caja 14, Año 1793, Carpeta: Borrador de una nota de la tesorería de Salta al comisionado Juan Cenarrusa para que cambien al soldado puesto en el recuento de mulas. Salta, 19 de febrero de 1793.

91 ABHS, FG, Caja 20, Año 1802, Carpeta Febrero. Tucumán, 16 de octubre de 1804. 
Las quejas por el sueldo bajo de los mencionados empleos y por las demoras en los pagos de los mismos fue una constante que se arrastraba desde la época colonial en todo el imperio y que no varió en el proceso revolucionario. De hecho, en 1812 en México se pedía que se suspendieran las deducciones salariales de los guardas para soportar las guerras, ya que de por sí estaban mal pagados. ${ }^{92}$

En un escrito que elevó José Fructuoso González a los ministros de Hacienda señaló que había servido más de nueve años en la tesorería de Salta a mérito y sin sueldo y luego siete años como dependiente del Resguardo. ${ }^{93}$ Pedía que certificasen que había trabajado siempre en las tareas de oficina al mismo tiempo que llevaba adelante su tarea de celar las ventas y custodiar los puestos de tránsito de mulas y vacas, todo "por un miserable sueldo". ${ }^{94}$

Los oficiales vinculaban también la penuria económica a los traslados a los que se habían visto forzados a hacer a causa de las ocupaciones realistas; encontramos pedidos de sueldos devengados por el tiempo en que se habían visto compelidos a habitar en Tucumán. En 1813 Fernández de Baldivieso decía al gobernador intendente que hacía seis meses que no gozaba de su sueldo como alcalde de Aduana. Expuso que estaba en estado de miseria, se hallaba en cama y había invertido su dinero en el traslado forzoso a Tucumán, suyo y de su familia. ${ }^{95}$

Pedro Lagrú, a la sazón tercer dependiente del resguardo, quien también se había retirado a Tucumán junto con el ejército, solicitaba que le pagaran todos los sueldos desde el 20 de febrero de 1813 y expresaba:

[...] es constante que para acreditar mi conocido patriotismo he dado los testimonios mas vivos en beneficio de la causa conduciéndome a la ciudad del Tucuman quando nuesto exercito verificó la retirada para aquel destino donde me he mantenido sirviendo con el mor empeño [...] y habiendo obtenido la gloria nuestras armas [...] tube la satisfacción de restituirme a mi casa donde he encontrado todos los intereses y corta pobresa sumamente destruidos por el enemigo; y después de estos contrastes y sin embargo de mi acreditada con-

92 Arnold, Burocracia y burócratas en México, 1742-1835, p. 101.

93 "La escasez de puestos de subordinados obligaba a los oficiales de la Real Hacienda a contratar, con sus propios ingresos, ayudantes suplementarios, los llamados amanuenses, aprendices que se iniciaban de esa manera en los arcanos administrativos de la Real Hacienda y trabajaban sin salario alguno, a no ser por los sueldos que los oficiales reales tuviesen a bien pagarles”. Bertrand, Grandeza y miseria del oficio. Los oficiales de la Real Hacienda de la Nueva España, siglos XVII y XVIII, p. 118.

94

ABHS, FG, Caja 28, Año 1811, Carpeta Noviembre. Tucumán, 25 de febrero de 1813. 
ducta me hallo privado de la renta y mensual quota que he obtenido por el empleo $\left[\ldots . .{ }^{96}\right.$

Lo mismo exigía el oficial auxiliar de las Cajas, Manuel Antonio Gallegos, quien desde marzo de ese mismo año no cobraba su sueldo. ${ }^{97}$ Como respuesta, en Salta, las entonces llamadas Cajas Nacionales, les adelantaron dinero a todos los empleados del Resguardo. ${ }^{98}$

Como en el resto de los cargos dependientes del "estado" vemos que las quejas sobre los sueldos fueron constantes, pero quizás paradójicamente, no se han registrado casi renuncias. La seguridad de un pago mensual, aunque se atrasara, la posibilidad del ascenso, y en algunos casos, la obtención de beneficios extras a veces vinculados a la actividad comercial, mantuvieron a estas personas ligadas a sus puestos.

\section{REFLEXIONES FINALES}

En el presente trabajo construimos el derrotero de los miembros del Real Resguardo y guardas vinculados al control del comercio desde Salta hacia el Alto Perú. Visualizamos quiénes eran esos guardas, cómo actuaron y cuáles fueron sus tareas en pleno proceso revolucionario para comprender los mecanismos de control y recaudación de la Hacienda. Seguimos las huellas de esos empleados, muchos de ellos presumiblemente españoles pobres; algunos involucrados con el comercio en detrimento de las arcas que debían cuidar; ocasionalmente, milicianos.

Durante el período revolucionario observamos que quienes venían ejerciendo esas tareas administrativas de control y recaudación en la Hacienda continuaron en sus cargos, rotaron o ascendieron gracias a sus carreras y permanencia dentro de esa institución. Sólo dos ingresos al Resguardo fueron excepcionales, aquéllos que tuvieron que ver con el nombramiento de milicianos premiados por sus servicios. Uno de esos nombramientos se dio en el período que nos ocupa, el otro fue anterior, ambos despertaron el descontento de los ministros a cargo. Las bajas por otra parte, se dieron por jubilaciones o fallecimientos, no hubo separaciones de esos cargos por otros motivos.

ABHS, FG, Caja 30 C, Año 1813, Carpeta Mayo. Salta, 11 de mayo de 1813.

Ibíd.

98 ABHS, FG, Caja 28, Año 1811, Carpeta Noviembre. Eran los empleados: Fernández de Baldivieso, Francisco Reyna, Pedro Lagrú, Manuel Antonio Gallegos y Ventura Rufo. Salta, 18 de junio de 1813. José Fructuoso González, dependiente del Resguardo. ABHS, FG, Caja 30 C, Año 1813, Carpeta Mayo. Salta, 19 de mayo de 1813. 
Como vimos, muchas problemáticas atravesaron el funcionamiento de este espacio, problemáticas que se arrastraban desde la colonia. La paga exigua y atrasada más la existencia de subcontratados o "sustitutos", cuyos estipendios eran costeados por el bolsillo de los oficiales a cargo. Observamos la falta de personal y de recambio de guardas para una tarea de control bastante dificultosa, así como también las malas condiciones de trabajo. Condiciones que creemos, repercutían en la eficiencia del trabajo.

El tema de las rutas a celar no fue menor, a pesar de que los caminos más aptos para el transporte de ganado parecen haber sido pocos (aunque extensos), se constata la existencia de otros que sin ser los mejores habrían permitido el paso evitando los puestos donde se encontraban los guardas. El control del territorio en general fue bastante dificultoso tanto en el período colonial como en el revolucionario al cual se suma un contexto de inestabilidad y violencia donde el dinero era demandado y requerido con urgencia por parte de jefes políticos y militares.

Como lo mencionáramos en el inicio, el objetivo a partir de esto fue analizar cómo funcionó este espacio intermedio de la administración de la Hacienda durante el período revolucionario, encargado de algo tan central como la recaudación y el control. La dinámica del funcionamiento del resguardo tuvo que ver explícitamente con el contexto, nuevas autoridades políticas, protagonismo del ejército y los vaivenes del comercio, reducido, prohibido, necesario. El escenario de guerra trastocó la vida en Salta tal y como se le conocía hasta junio de 1810 y el Resguardo no fue la excepción. Ahora bien, desde el punto de vista organizativo, salvo por el ingreso de un dependiente gracias a sus servicios a "la Patria” la revolución política no afectó este espacio.

Habría que esperar entonces, hasta 1821, para ver los cambios operados a raíz de la propuesta de un nuevo reglamento administrativo provincial.

\section{BibLIOGRAFÍA}

Acevedo, Edberto, La intendencia de Salta del Tucumán en el virreinato de Río de la Plata, Mendoza, UNCuyo, 1965.

— L L Levolución de Mayo en Salta, Salta, EUCASA, 2010.

Aramendi, Bárbara, "En lo más bajo de la administración colonial: guardas y receptores de la Real Hacienda. Salta, siglo XVIII", Anuario del Centro de Estudios Históricos “Prof. Carlos S. A. Segreti”, núm. 9, 2009, pp. 183-197.

— caso de la Real Hacienda en Jujuy”, Memoria Americana, vol. 22, núm. 2, 2014, pp. 91-110.

Arnold, Linda, Burocracia y burócratas en México, 1742-1835, México, Grijalbo [1988] 1991. 
Assadourian, Carlos y Palomeque Silvia, "Los circuitos mercantiles del "interior argentino” y sus transformaciones durante la Guerra de la Independencia (1810-1825)", en Bandieri Susana, La historia económica y los procesos de independencia en la América hispana, Prometeo, Buenos Aires, 2010, pp. 49-69.

Barriera, Darío, “Introducción”, Instituciones, gobierno y territorio. Rosario, de la Capilla al Municipio (1725-1930), Rosario, ISHIR CONICET, 2010, pp. 916.

Bertrand, Michel, “De la familia a la red de sociabilidad”, Revista Mexicana de Sociología, vol. 61, núm. 2, 1999, pp. 107-135.

, "Los oficiales reales de Nueva España: una aproximación al estudio de un grupo de poder en la sociedad novohispana (siglos XVII-XVII)”, en Menegus, Margarita, Universidad y sociedad en Hispanoamérica. Grupos de poder siglos XVIII у XIX, México, UNAM, 2001, pp. 15-39.

_- Grandeza y miseria del oficio. Los oficiales de la Real Hacienda de la Nueva España, siglos XVII y XVIII, México, FCE, [1999] 2011.

Bertrand Michel y Moutoukias, Zacarías (eds.), Cambio institucional y fiscalidad: Mundo hispánico, 1760-1850, Madrid, Casa de Velázquez, 2018.

Brackebusch, Luis, Por los caminos del Norte, Jujuy, UNJu, 1990.

Burkholder, Mark, “Burócratas”, en Hobermas, L. y Socolow, S. (comps.), Ciudades y sociedad en Latinoamérica colonial, Buenos Aires, Fondo de Cultura Económica, 1993, pp. 105-140.

Burkholder, Mark y Chandler, Dewitt, De la impotencia a la autoridad, la corona española y las audiencias en América, 1687-1808, México, FCE, [1977] 1984.

Castellano, Juan Luis et. al., La pluma, la mitra y la espada. Estudios de Historia Institucional en la Edad Moderna, Madrid, Universidad de Burdeos, 2000.

Conti, Viviana, Articulaciones mercantiles del espacio saltojujeño durante el período rosista, La Plata, UNLP, Facultad de Humanidades y Ciencias de la Educación, 2005. Disponible en:

www.memoria.fhace.unlp.edu.ar/tesis/te.228/te.228.pdf

, “Jujuy en 1810”, en Lagos, Marcelo y Conti Viviana, Jujuy de la Revolución a nuestros días.1810-1910-2010, Jujuy, EDIUNJu, 2010.

, "Reordenamiento de las rentas fiscales en la emergencia de los estados provinciales. Salta y Jujuy (1835-1853)”, Travesía, núm. 14-15, 2012-2013, pp. 7-30.

Conti, Viviana y Sica, Gabriela, “Arrieros andinos de la colonia a la independencia. El negocio de la arriería en Jujuy, Noroeste Argentino”, Nuevo Mundo Mundos Nuevos. Debates, 2011.

Costa, María, "La élite jujeña a fines del período colonial. Gobernaciones Intendencias, pérdidas de privilegios y usos de la justicia (Argentina, siglos XVIII-XIX), Americania, núm. 4, Sevilla, 2016, pp. 161-192. 
De la Cuesta, Marta, Organización institucional de Salta (1821-1855), Salta EUCASA, 1999.

Delgado Ribas, Josep, “Fiscalidad y comercio con América: los Resguardos de Rentas de Catalunya (1778-1799)”, Boletín Americanista, núm. 30, 1980, pp. 6988.

Dubet Anne y Solbes Ferri Sergio (pres.), Dossier "La construcción de la hacienda hispánica en el largo siglo XVIII”, Melanges de la Casa de Velázquez, vol. 46, núm. 1, 2016. Publicado el 1 de enero de 2018, http://journalsopenedition.org/mcv/6731, consultado el 13 de noviembre de 2019.

Fisher, John, Gobierno y sociedad en el Perú colonial. El régimen de las Intendencias: 1784-1814, Lima, Pontificia Universidad Católica del Perú, [1970] 1981.

Imízcoz, José María (dir.), Élites, poder y red social. Las élites del País Vasco y Navarra en la Edad Moderna, Universidad del País Vasco, Bilbao, 1996.

- Redes familiares y patronazgo. Aproximación al entramado social del País Vasco y Navarra en el Antiguo Régimen (siglos XV-XIX), Bilbao, Universidad del País Vasco, 2001.

Lynch, John, Administración colonial española: el sistema de intendencias en el Virreinato del Río de la Plata, Buenos Aires, EUDEBA, 1962.

Madrazo, Guillermo, "El comercio regional en el siglo XIX. La situación de Salta y Jujuy”, Andes, núm. 7, pp. 221-249.

Mariluz Urquijo, José María (dir.), Estudios sobre la Real Ordenanza de Intendentes del Río de la Plata, Buenos Aires, Instituto de Investigaciones de Historia del Derecho, 1995.

Mata, Sara, "La guerra de independencia en Salta y la emergencia de nuevas relaciones de poder”, Andes, núm. 13, 2002, pp. 1-22.

"Salta y la guerra de la independencia en los Andes Meridionales", Jahrbuch Für Geschichte Lateinamerikas, num. 41, 2004, pp. 223-245.

— - Tierra y poder en Salta. El noroeste argentino en vísperas de la independencia, Salta CEPIHA, Facultad de Humanidades, UNSa, 2005.

— , "Guerra, militarización y poder. Ejército y milicias en Salta y Jujuy. 18101816”, Anuario del IHES, núm. 24, 2009, pp. 279-298.

Phelan, John, El Reino de Quito en el siglo XVII. La política burocrática en el Imperio Español, Quito, Banco Central del Ecuador, [1967] 1995.

Pietschmann, Horst, Las reformas borbónicas y el sistema de intendencias en Nueva España. Un estudio político administrativo, México, Fondo de Cultura Económica, 1996.

Sánchez Albornoz, "La saca de mulas de Salta al Perú, 1778-1808”, Anuario del Instituto de Investigaciones Históricas de Rosario, núm. 18, 1968, pp. 262311. 
Socolow, Susan, The Bureaucrats of Buenos Aires, 1769-1810: Amor al Real Servicio, United States, Duke University Press, Durham and London, 1987.

Solá, Miguel, "Salta (1810-1821)”, Historia de la Nación Argentina, Buenos Aires, Academia Nacional de la Historia, tomo 10, El Ateneo, 1947, pp. 365-401.

Solbes, Sergio et. al., "Introducción. Actores políticos y actores privados en el gobierno de la Hacienda”, Tiempos Modernos, vol. 8, núm. 30, 2015. Disponible en: $\quad$ www.tiemposmodernos.org/tm3/index.php/tm/article/download/427/458, consultado el día 17 de mayo de 2019.

Ternavasio, Marcela, Gobernar la Revolución. Poderes en disputa en el Río de la Plata, 1810-1816, Buenos Aires, Siglo XXI, 2016.

Tío Vallejo, Gabriela, “Antiguo Régimen y liberalismo. Tucumán, 1770-1830, Tucumán”, Cuadernos de Humanitas, Facultad de Filosofía y Letras, Universidad Nacional de Tucumán, 2001.

Wayar, Alejandro, "La estructura fiscal de la Intendencia de Salta. 1800-1809”, XI Encuentro de Historia Regional Comparada. Siglos XVI a mediados del XIX, Programa Interuniversitario de Historia Social Enfoque Regional (PIHSER), Salta, 21 y 22 de mayo 2009, inédito. 